\title{
STOLICA APOSTOLSKA W POLSKIEJ POLITYCE ZAGRANICZNEJ NA UCHODŹSTWIE (WRZESIEŃ 1939 - CZERWIEC 1940)
}

Słowa kluczowe: Stolica Apostolska, Polska, II wojna światowa, Pius XII

Keywords: Holy See, Poland, World War II, Pius XII

rtykuł niniejszy jest próbą spojrzenia na politykę papieża Piusa XII

i Stolicy Apostolskiej wobec sprawy Polski po katastrofie jaką przyniósł naszemu narodowi Wrzesień 1939 r. Terminus ad quem naszych rozważań stanowi klęska Francji w czerwcu 1940 r. oraz przeniesienie rządu RP na uchodźstwie do Londynu, które otworzyło nowy rozdział jego losów. Wyłączamy z naszej analizy takie problemy jak akcja charytatywna Watykanu; problem administracji kościelnej w okupowanej Polsce czy stosunki z episkopatem polskim. Koncentrujemy natomiast uwagę na zagadnieniach polityki międzynarodowej, poszukując odpowiedzi na pytanie o miejsce kwestii polskiej w dyplomacji Watykanu.

O podejściu Stolicy Apostolskiej i papieża Piusa XII do spraw Polski podczas II wojny światowej pisano już wiele - niestety wyłącznie na podstawie

1 Katedra Historii Stosunków Międzynarodowych, Instytut Prawa Międzynarodowego, Unii Europejskiej i Stosunków Międzynarodowych, Wydział Prawa i Administracji, Uniwersytet Kardynała Stefana Wyszyńskiego w Warszawie. 
polskich akt archiwalnych, przede wszystkim dyplomatycznych. Ogłoszona ponad trzydzieści lat temu monografia Zofii Waszkiewiczowej pozostaje wciąż jednak jedynym całościowym studium na ten temat w polskiej historiografii ${ }^{2}$. Nowszym spojrzeniem jest szkic czołowego znawcy polityki papiestwa w XIX i XX w., ks. Zygmunta Zielińskiego zamieszczony w piątym tomie Historii dyplomacji polskiej ${ }^{3}$. Z publikacji ostatniego czasu przypomnieć wypada dwa moje artykuły źródłowe - zamieszczone w paryskich „Zeszytach Historycznych"4. Przyniosły one sporo światła do zrozumienia motywacji papieża i Sekretariatu Stanu, chociaż na pewno wymagają konfrontacji z dokumentacją drugiej strony, czyli watykańską.

Niedostępność akt archiwalnych Stolicy Apostolskiej jest poważną barierą dla badacza. Akta polskiej dyplomacji rzucają wszakże sporo światła na stosunki Polski z Watykanem. Rekonstrukcję myśli papieża i usiłowań Stolicy Apostolskiej pozwalają uzupełnić akta dyplomatyczne innych państw - zwłaszcza francuskie i brytyjskie.

Naszym celem nie jest wszakże analiza polityki watykańskiej, ale polskich działań na rzecz uzyskania poparcia Stolicy Apostolskiej dla Polski i jej sprawy po klęsce Września 1939 r. Bardzo potrzebne jest, aby o polityce Piusa XII starać się mówić i pisać sine ira et studio, bezwzględnie odrzucając szkalujące oskarżenia, insynuujące że był „papieżem Hitlera”, ale też nie omijając analizy jego posunięć, które z dystansu czasu nie wytrzymują krytyki.

Klęska militarna i opanowanie przez wrogie mocarstwa terytorium Polski wytworzyła problem prawnomiędzynarodowej ciągłości państwa ${ }^{5}$. Obję-

2 Z. Waszkiewicz, Polityka Watykanu wobec Polski 1939-1945, PWN, Warszawa 1980. Autorka nie korzystała z akt Ambasady RP przy Watykanie.

3 Z. Zieliński, Polska - Watykan w latach 1939-1945, [w:] Historia dyplomacji polskiej, t. 5, red. G. Labuda, PWN, Warszawa 1999, s. 711-739.

${ }^{4}$ M. Kornat, Ambasador Kazimierz Papée - piętnaście rozmów z papieżem Piusem XII, „Zeszyty Historyczne” 2006, z. 156 s. 124-178; idem, Watykan i Polska (1939-1944) w świetle dokumentów, „Zeszyty Historyczne” 2006, z. 157, s. 168-228.

${ }^{5}$ Stanowisko Watykanu wobec rozbioru Rzeczypospolitej analizowałem w obszernym artykule: Polityka Stolicy Apostolskiej w dobie kryzysu międzynarodowego 1938-1939 (w świetle polskich źródeł dyplomatycznych), [w:] Kampania polska 1939 r. Polityka - społeczeństwo - kultura, t. I: Strategia, red. M.P. Deszczyński, T. Pawłowski, Warszawa 2013, s. 323-371. 
:::: Marek Kornat, Stolica Apostolska w polskiej polityce zagranicznej...

cie urzędu Prezydenta Rzeczypospolitej na uchodźstwie przez Władysława Raczkiewicza 30 września 1939 r. i powołanie rządu generała Władysława Sikorskiego zostało zakomunikowane Stolicy Apostolskiej notami Ambasady RP przy Watykanie 1 i 5 października. Papieski Sekretariat Stanu notą z 11 października potwierdził odbiór wspomnianych dokumentów „zawiadamiających o zmianie na stanowisku Prezydenta RP oraz o stworzeniu nowego rządu”6. Notyfikacja polska "nie napotkała na żadne zastrzeżenia natury prawnej"7. Ze strony papiestwa nie było żadnych wątpliwości co do prawnopaństwowej ciągłości Polski poprzez działanie rządu na uchodźstwie. Stolica Apostolska kierowała się taką samą tezą jak cała społeczność międzynarodowa - z wyjątkiem Niemiec i ZSRR jako wspólników agresji i rozbioru.

Stolica Apostolska nie zdobyła się na wysłanie nuncjusza do siedziby Rządu RP w Angers. Rządowi RP i samemu gen. Sikorskiemu było to bardzo nie na rękę. Nuncjusz Filipo Cortesi, który wraz z korpusem dyplomatycznym (którego był dziekanem) przekroczył granicę Rumunii, zatrzymał się tam i nie przybył do Francji. W rozmowach z przedstawicielami Kurii Rzymskiej dyplomaci polscy wracali do tej sprawy wielokrotnie. Watykański Sekretariat Stanu powoływał się za każdym razem na potrzebę, aby nuncjusz „na razie” pozostał w Rumunii i kierował tam akcją pomocy charytatywnej na rzecz uchodźców polskim w Rumunii.

Niewątpliwie opuszczenie przez nuncjusza terytorium Rzeczypospolitej było papieżowi nie na rękę. Jego pozostanie bowiem w okupowanym kraju dawałoby Stolicy Apostolskiej informatora o sytuacji pod okupacją niemiecką albo też postawiłoby władze niemieckie przed koniecznością wydalenia nuncjusza. Jest również faktem, że msgr Cortesi sporządził nieznany nam raport końcowy, podsumowujący swoją przerwaną misję w Polsce, ale dokument ten - przechowywany w archiwach watykańskich - po dziś dzień nie został ogłoszony ${ }^{8}$.

${ }^{6}$ Amb. Papée do MSZ, 12 października 1939 r., Instytut Polski i Muzeum Sikorskiego (Londyn) [dalej: IPMS], Ambasada RP przy Watykanie, sygn. A. 44. 122/20.

7 Papée do MSZ, 6 października 1939 r., IPMS, Ambasada RP przy Watykanie, sygn. A. 44.122/20.

8 Watykańskie Archivio Segreto nie udostępnia historykom akt misji ostatniego nuncjusza przy rządzie II Rzeczypospolitej. 
Rząd RP na uchodźstwie od początku nalegał na wysłanie nuncjusza do siedziby Prezydenta RP we Francji, powołując się na zasady prawa międzynarodowego. Nie trzeba nikomu tłumaczyć, jak bardzo istotną wymowę polityczną miałby taki gest ${ }^{9}$. Chargé d'affaires Stanisław Janikowski nie pominął okazji by zaznaczyć wobec urzędników Sekretariatu Stanu, że „Cortesi, jako Nuncjusz, znalazłby się w trudnej sytuacji, gdyby natknął się w Polsce na próby tworzenia rządu przez Niemców"10. Rząd RP na uchodźstwie uważał, że miejsce msgra Cortesi jest przy rządzie polskim we Francji. Nie nastąpiło to jednak.

Po niełatwych targach, do siedziby rządu RP na uchodźstwie w Angers wysłany został prałat Alfredo Pacini jako chargé d'affaires, a nie nuncjusz. Zarazem Sekretariat Stanu prosił dyplomację polską, aby nie nadawać tej sprawie rozgłosu ${ }^{11}$. Wszelka propolska manifestacja zaostrzająca stosunki z Niemcami jawiła się bardzo niecelowa. Papież chciał przede wszystkim zachować sobie możliwość mediacji między stronami konfliktu.

Przy Watykanie kontynuowała swoją działalność Ambasada RP, kierowana nadal przez Kazimierza Papéego, która starała się pełnić rolę placówki informacyjnej zarówno Sekretariatu Stanu, jak i przede wszystkim wobec dziennika "Osservatore Romano” w zakresie spraw polskich ${ }^{12}$. 29 października 1940 r. ambasador złożył w Sekretariacie Stanu cztery memoriały i jedno „zasadnicze”, obszerne aide-mémoire o położeniu okupowanej Polski w języku francuskim ${ }^{13}$. Memoriał zrobił w Kurii Rzymskiej duże wrażenie ${ }^{14}$. „Mimo wszystko - pisał Papée - nie bardzo widzę, aby mogło dojść do jakiejś enuncjacji”15. Rezultaty tej akcji były ograniczone, chociaż nie bez znaczenia.

9 Słusznie podkreśla to ks. Z. Zieliński, op.cit., s. 714-717.

${ }^{10}$ Janikowski do MSZ, 17 października 1939 r., IPMS, Ambasada RP przy Watykanie, sygn. A. 44.122/20.

${ }_{11}$ Amb. Papée do min. Raczyńskiego, 21 grudnia 1941 r., Ambasada RP przy Watykanie, sygn. A. 44. 122/20.

12 Papée do MSZ, 11 października 1939 r., IPMS, Ambasada RP przy Watykanie, sygn. A. 44.122/20.

${ }^{13}$ IPMS, Ambasada RP przy Watykanie, sygn. A. 44. 122/24.

14 Amb. Papée do kard. Hlonda w Lourdes, 12 listopada 1940 r., IPMS, Ambasada RP przy Watykanie, sygn. A. 44.122/24.

${ }^{15}$ Ibidem. 


\section{:::: Marek Kornat, Stolica Apostolska w polskiej polityce zagranicznej...}

Znamienny jest jeden z dokumentów dyplomacji francuskiej. 7 października 1939 r. ambasador francuski François Charles-Roux, relacjonując rozmowę radcy Ambasady Francuskiej przy Watykanie Jean Rivière'a z zastępcą sekretarza stanu monsignorem Giovannim Battistą Monitinim pisał, że Watykan na razie nie sformułował żadnego stanowiska w sprawie notyfikacji powstania rządu generała Sikorskiego ${ }^{16}$. Watykan - tłumaczył Montini - kieruje się stanowiskiem realistycznym i przypomniał, że „les conseils données lors de la dernière guerre par le Vatican, aux populations belges, d'obeir aux autorités allemandes d'occupation". Ambasador francuski, w piśmie do własnego MSZ w Paryżu dał następujący komentarz do tych słów: „Ces rémarques éclairaient bien la mentalité qui semble règne actuellement au Saint-Siège et que l'on peut caracteriser ainsi: la résignation devant le fait accompli"17.

20 października 1939 r. Pius XII ogłosił swoją programową encyklikę Summi Pontificatus. Polsce poświęcił następujący fragment:

„Czyż potrzebujemy was zapewniać, że Nasze ojcowskie serce obejmuje miłością pełną współczucia wszystkie Nasze dzieci, a zwłaszcza te, które spotkała krzywda i prześladowania? (...) Krew tysięcy ludzi, nawet tych, którzy nie brali udziału w służbie wojskowej, a jednak zostali zabici, zanosi bolesną skargę zwłaszcza w Polsce, która - dla swej niezłomnej wierności dla Kościoła i dla wielkich zasług, jakie zdobyła broniąc chrześcijańskiej kultury i cywilizacji o czym historia nigdy nie zapomni - ma słusznie jej należne prawo do ludzkiego i braterskiego współczucia całej ludzkości. Położywszy swą ufność w Bogarodzicy Dziewicy, «Wspomożycielce Wiernych»", czeka ona upragnionego dnia, w którym, jak tego domagają się zasady sprawiedliwości i prawdziwie trwałego pokoju, wyłoni się wreszcie zmartwychwstała z owego jakby potopu, który się na nią zwalił"18.

Słowa dotyczące Polski zasługują na uważną analizę z punktu widzenia jej sprawy ${ }^{19}$. Po pierwsze, $\mathrm{w}$ tekście nie ma komentarza wymieniające-

\footnotetext{
${ }^{16}$ Archives du Ministère des Affaires Étrangères (Paryż) [dalej skrót: AMAE], serie: Europe 1918-1940, Saint-Siège, t. 329.

17 Ibidem.

18 Summi Pontificatus: Encyklika Papieża Piusa XII z dnia 20 października 1939 roku, Te Deum, Warszawa 1998, s. 40.

19 Międzynarodowe echa encykliki streściła zwięźle Z. Waszkiewicz, op.cit., s. 44-47.
} 
go sprawców nieszczęścia Polski, padły zaś słowa współczucia i deklaracja o potrzebie jej „zmartwychwstania”. Po drugie, w Summi Pontificatus Pius XII ustalił swoisty model dyskursu Stolicy Apostolskiej o Polsce i jej sprawie na cały okres II wojny światowej, który będzie kontynuowany w rozmaitych enuncjacjach publicznych. Po trzecie, występuje wyraźna analogia między programową encykliką Piusa XII, ubolewającego nad losem Polski, programową encykliką Benedykta XV (Ad Beatissimi Apostolorum), w której ów papież kierował słowa pocieszenia do narodu napadniętej i okupowanej Belgii w 1914 r. „Narody nie umierają” - dodał rok później.

Stając wobec tragedii Polski, Pius XII planował możliwie szeroko zakrojoną akcję pomocy charytatywnej, która - jak donosił w telegramie szyfrowym z 17 października 1939 r. ministrowi spraw zagranicznych Augustowi Zaleskiemu ambasador Papee - „zostanie rozszerzona do skali międzynarodowej” ${ }^{20}$. Na to wszakże nie pozwolili, jak wiadomo, Niemcy.

Jeszcze pod koniec października 1939 r. Janikowski informował MSZ w Paryżu, iż Watykan „szuka formy” dla szerszej akcji charytatywnej ${ }^{21}$. Nie miała ona żadnych szans realizacji w obliczu barbarzyńskich metod prowadzenia wojny przez III Rzeszę. Monsignor Montini mówił ambasadorowi RP, iż chodzi o „otrzymanie pozwolenia rządu niemieckiego na tego rodzaju papieską akcję pomocy"22. Watykan zwrócił się do władz niemieckich o takie pozwolenie przez swojego nuncjusza w Berlinie Cesare Orsenigo. Montini tłumaczył 1 grudnia 1939 r. Papéemu, że „Watykan nie myśli już długo czekać i że sprawa musi być zdecydowana w najbliższym czasie"23. Definitywnie 18 grudnia 1939 r. Sekretariat Stanu poinformuje tylko Papéego, iż nuncjusz w Berlinie Orsenigo nie dostał żadnej odpowiedzi na swoje prośby w tej sprawie żądanie pomocy dla Polski ${ }^{24}$.

${ }^{20}$ W. Rojek (red.), Polskie Dokumenty Dyplomatyczne. Wrzesień - grudzień 1939, PISM, Warszawa 2007, s. 208.

${ }^{21}$ IPMS, Ambasada RP przy Watykanie, sygn. A.44.122/20. Raport amb. Papéego z 26 październik $1939 \mathrm{r}$.

22 Papée do min. Zaleskiego, 1 grudnia 1939 r., IPMS, Ambasada RP przy Watykanie, sygn. A. 44.122/20.

${ }_{23}$ Dokument nosił tytuł: Protestation du Général Sikorski au nom du Gouvernement Polonais contre les atrocités allemandes (IPMS, Ambasada RP przy Watykanie, sygn. A.44.122/20, załącznik do raportu amb. Papéego z 18 grudnia 1939 r.).

24 IPMS, Ambasada RP przy Watykanie, sygn. A.44.122/20. Pismo Papéego do ministra Zaleskiego z 18 grudnia 1939 r. 
:::: Marek Kornat, Stolica Apostolska w polskiej polityce zagranicznej...

Mimo stwarzanych przeszkód, papież starał się prowadzić na ile to możliwe akcję charytatywną na rzecz okupowanej Polski ${ }^{25}$. Przy nuncjaturze przy rządzie włoskim powołane nawet zostało Biuro Pomocy Jeńcom i Uchodźcom Polskich ${ }^{26}$. Stolica Apostolska subsydiowała Polski Czerwony Krzyż, wspierała także Radę Główną Opiekuńczą ${ }^{27}$. Wiadomo, że prezes tej instytucji Adam Ronikier o pomoc taką prosił przez ambasadora Papéego, uzyskując z nim nieformalny tajny kontakt ${ }^{28}$. Określone środki finansowe otrzymywał też z Watykanu kard. Hlond, który nimi dysponował, wspierając w ten sposób diecezje w kraju i tajne seminaria. Papież polecił mu również rozwinąć akcję pomocy charytatywnej na rzecz uchodźstwa polskiego w Europie i jeńców polskich we Francji, Rumunii i na Węgrzech ${ }^{29}$.

„We wszystkich wypowiedzeniach Mgr. Montini - pisał w jednym ze swych raportów z jesieni 1939 r. ambasador Papée - uderzało bardzo silne, powiedziałbym jeszcze wzmożone nastawienie przeciw III Rzeszy, idące w parze ze szczerą chęcią zrobienia czegoś dla Polski”. I dopowiadał, że „to samo nastawienie uderzyło mnie we wszystkich rozmowach, które ostatnio przeprowadziłem z członkami Kolegium Kardynalskiego". Życzliwe i rzeczowe wobec spraw polskich stanowisko Montiniego kontrastowało z bardzo wyważonym i chłodnym nastawieniem jego zwierzchnika kard. Maglione. Kiedy w grudniu 1939 r. ambasador Papée przedstawił kardynałowi informacje o zbrodniach niemieckich w Polsce, kardynał nie bez ironii odpowiedział, że Niemcom nie wiele można udowodnić, bo oni „potrafią wszystkiemu przeczyć" ${ }^{30}$.

${ }^{25}$ Amb. Papée był miarodajnym świadkiem tej akcji. (raport z 6 września 1940 r., IPMS, Ambasada RP przy Watykanie, sygn. A. 44.122/23).

${ }^{26}$ Nota kard. Maglione do amb. Papéego z 11 stycznia 1941, IPMS, Ambasada RP przy Watykanie, sygn. A. 44.122/25.

${ }^{27}$ Czynił to Pius XII poprzez ręce arcybiskupów Sapiehy i Szeptyckiego, gdyż bezpośrednie dotacje uniemożliwiły okupacyjne władze niemieckie - B. Kroll, Rada Główna Opiekuńcza 1939-1945, Warszawa 1985, s. 147-148). Nie poświęca tej sprawie uwagi Adam Ronikier w swych nader interesujących Pamiętnikach 1939-1945, Kraków 2001.

${ }^{28}$ Papée do Zaleskiego, 9 grudnia 1940 r., IPMS, Ambasada RP przy Watykanie, sygn. A. 44.122/24.

${ }^{29}$ Amb. Papée do kard. Hlonda w Lourdes, 12 listopada 1940 r., IPMS, Ambasada RP przy Watykanie, sygn. A. 44.122/24.

${ }^{30}$ Protestation du Général Sikorski. 
Z własnej inicjatywy Stolica Apostolska zabiegała u rządu Rzeszy Niemieckiej o powrót Prymasa kard. Augusta Hlonda do okupowanego kraju - do swojej opuszczonej we wrześniu 1939 r. diecezji. W telegramie z 4 października Janikowski informował polskie MSZ w Paryżu o tych staraniach, zaś monsignor Domenico Tardini mówił, „że są pewne szanse”31. „Notabene - jak meldował do MSZ na uchodźstwie ambasador Papée - Ks. Prymas jest usposobiony sceptycznie co do wyniku tych zabiegów"32.

I w tym wypadku niezwykle ostrożna taktyka Piusa XII wobec III Rzeszy nie dała rezultatu. Ambasador francuski Charles-Roux informował 8 października Quai d’Orsay, że Watykan będzie prosił władze niemieckie, aby kardynał Hlond mógł wrócić do swej opuszczonej we wrześniu 1939 r. diecezji, ale już 3 listopada okazało się, że Niemcy odmówiły wpuszczenia kard. Hlonda i konstatował niepowodzenie polityki Piusa XII. 9 grudnia Tardini poinformował Charlesa-Roux o definitywnie negatywnej odpowiedzi rządu niemieckiego w sprawie prymasa Hlonda.

W tych warunkach Sekretariat Stanu rozpatrywał jeszcze inny pomysł - wysłania do Polski jakiegoś przedstawiciela kościelnego, rozważając np. „jakiegoś jezuitę hiszpańskiego”, który otrzymałby uprawnienia wizytatora kościelnego, na wzór doświadczeń I wojny światowej, kiedy w takim charakterze skierowano w maju 1918 r. do Warszawy monsignora Achille Rattiego. Nadzwyczajna misja do okupowanej Polski dałaby Stolicy Apostolskiej przede wszystkim dostęp do informacji o położeniu Kościoła pod okupacją niemiecką. Jak można było się spodziewać, ze strony Auswärtiges Amt w Berlinie nastąpiła kategoryczna odmowa wpuszczenia wysłannika Stolicy Apostolskiej ${ }^{33}$. Nastąpiło to 17 listopada 1939 r. Koncepcja skierowania wizytatora apostolskiego do Polski upadła ${ }^{34}$. Będzie ona jeszcze wznowiona w marcu 1940 r. - bezskutecznie.

Polski rząd na uchodźstwie przykładał wielką wagę do stanowiska Stolicy Apostolskiej wobec toczącej się wojny, wychodząc z założenia, że ciężar

31 Papée do MSZ, 4 października 1939 r., IPMS, Ambasada RP przy Watykanie, sygn. A.44.122/20.

32 IPMS, sygn. A.44.122/20, Papée do Zaleskiego, 23 października 1939 r.

33 AMAE, Europe 1918-1940, Saint-Siège, vol. 329 (telegram szyfr. Jean Rivière'a do MSZ w Paryżu z 7 listopada 1939).

${ }^{34}$ Amb. Papée do min. Zaleskiego, 17 listopada 1939 r., IPMS, Ambasada RP przy Watykanie, sygn. A. 44.122/20. 
moralny głosu papieża jest sprawą wielkiej wagi i należy o jego wypowiedź w obronie Polski wytrwale zabiegać. W polskim kierownictwie politycznym na uchodźstwie uznał przemówienie papieża do pielgrzymów polskich - zebranych pod przewodnictwem kardynała-prymasa Augusta Hlonda wygłoszone 29 września 1939 r. w Rzymie oraz encyklikę Summi Pontificatus z 20 października 1939 r. - za niewystarczające ${ }^{35}$. Nie przyniosła skutku francuska nota z 29 września 1939 r., w której kierujący resortem spraw zagranicznych w Paryżu premier Édouard Daladier prosił o potępienie napaści na Polskę oraz jasne przypomnienie zasad moralnych, które jednakowo obowiązują jednostki i narody ${ }^{36}$.

Dyplomacja rządu polskiego na uchodźstwie podejmowała nieustające wysiłki o uzyskanie ze strony papieża nowego, idącego dalej, publicznego wystąpienia, potępiającego imiennie agresję na Polskę i dokonane na ziemiach polskich zbrodnie wojenne oraz zbrodnie przeciwko narodowi polskiemu. Wysiłki dyplomacji polskiej natrafiły w tej sprawie na trudności spowodowane własną, jak się wydaje, przemyślaną motywacją papieża, aby powstrzymać się od jednoznacznego potępienia hitleryzmu i zbrodni nazistowskich.

Jednym z pomysłów rządu RP na uchodźstwie było usiłowanie wywarcia na papieża wpływu poprzez wywołanie głosu wyższych hierarchów Kościoła. Podjęto próbę nakłonienia do wspólnego wstąpienia w sprawach polskich do papieża ze strony kardynałów: Arthura Hinsleya (arcybiskupa Westminsteru) i Jeana Verdiera (metropolity Paryża) ${ }^{37}$. W akcję mobilizacji dla Polski przywódców świata katolickiego Zachodu włączył się prymas Hlond. Pisał on listy do kardynałów: Hinsleya, Josepha-Ernesta Van Roey’a

35 O znaczeniu encykliki Summi Pontificatus zob. uwagi Zofii Waszkiewicz, op.cit., s. 44-47. Warto wspomnieć, że 26 września 1939 r. papież przyjął na audiencji pielgrzymów niemieckich i wygłosił do nich przemówienie - jego tekst: Actes et documents du Saint Siège relatifs à la Seconde Guerre Mondiale, t. I: Le Saint Siège et la guerre en Europe, Libr. Ed. Vaticana, Città del Vaticano 1965, dok. 210, s. 313. Wojnę, która wybuchła określił papież jako „dopust Boży” (Gottesgeissel). Mowy do Polaków wydawnictwo - z niejasnych powodów - nie zawiera.

${ }^{36}$ Notę wręczył ambasador Charles-Roux kard. Maglione 2 października (fragmenty cytuje Z. Waszkiewicz, op.cit., s. 42-43).

${ }^{37}$ AMAE, Europe, 1918-1940, Saint-Siège, vol. 329 (telegram szyfrowy ambasadora francuskiego w Londynie Charlesa Corbina do MSZ na Quai d'Orsay z 30 października 1939 r.). 
(prymasa Belgii), Manuela Gonçalvesa Cerejeiry (patriarchy Lizbony), Isidora Goma y Tomas (prymasa Hiszpanii). Papée doradził, aby zwrócić się jeszcze do metropolitów Copello z Buenos Aires i Villeneuve z Montrealu ${ }^{38}$. Argentyński kardynał zdecydował się na organizację transportu ciepłych ubrań i lekarstw do Rumunii dla uchodźców polskich.

Dyplomacji polskiej udało się uzyskać specjalne enuncjacje w obronie Polski ze strony niektórych członków episkopatu francuskiego - w myśl hasła poparcia dla „Polski męczeńskiej” (Pologne-martyre). 8 maja 1940 r. kard. Hinsley wygłosił kazanie, w którym mówił o „bezwzględnym okrucieństwie najeźdźców Polski i jej prześladowców” oraz o tym, że „droga Polska ma prawo do ludzkiego współczucia całego świata", cytując tu słowa Piusa XII z Summi Pontificatus. W obronie Polski wystąpił także kardynał-patriarcha Lizbony Cerejeira. Papée mówił także o istnieniu w Kurii Rzymskiej pewnego odłamu życzliwych sprawie polskiej hierarchów. Wystąpienia te nie skłoniły wszakże Piusa XII do zmiany taktyki dyplomatycznej i do bardziej otwartej enuncjacji potępiającej napaść na Polskę.

Szeroką akcję na rzecz zmiany stanowiska Stolicy Apostolskiej wobec Polski rozwinął Hlond. Już w styczniu 1940 r. znany memoriał Hlonda o położeniu Kościoła w okupowanej Polsce, został złożony w Watykanie ${ }^{39}$. Prymas działał w porozumieniu z ambasadą RP. Opracowanie źródłowe pt. The Persecution of the Catholic Chuch in German Occupied Poland, przygotowane na podstawie materiałów zebranych przez polskiego kardynała zostało ogłoszone w językach zachodnich ${ }^{40}$.

Kierownictwo polskiej dyplomacji zabiegało o poparcie polskich starań przez rządy mocarstw alianckich, wierząc że „tylko zjednoczony front państw pokrzywdzonych i potężnych aliantów przedstawia pewne szanse uzyskania zmiany dotychczasowego stanowiska Piusa XII, będącego linią

\footnotetext{
${ }^{38}$ IPMS, Ambasada RP przy Watykanie, sygn. A.44.122/20. Papée do MSZ, 23 października $1939 \mathrm{r}$.

${ }_{39}$ Amb. Papée do min. Zaleskiego, 29 maja 1940 r., IPMS, Ambasada RP przy Watykanie, sygn. A. 44. 122/21.

${ }^{40}$ London 1941 r. (przemowę do broszury napisał kard. Hinsley). Analizę tych dokumentów dał ks. S. Wilk (oprac.), Raporty kardynała Hlonda o sytuacji Kościoła w Polsce podczas okupacji hitlerowskiej w Polsce, „Chrześcijanin w Świecie” 1978, nr 10, s. 13-53.
} 
:::: Marek Kornat, Stolica Apostolska w polskiej polityce zagranicznej...

„di imparzialità assoluta” w toczącej się wojnie ${ }^{41}$. Papież w grudniu $1941 \mathrm{r}$. przyznał nawet, że sam narzucił sobie rezerwę, aby nie podejrzewać go o stronniczość.

Pierwsza w dobie wojny mowa papieża do Kolegium Kardynalskiego wygłoszona w wigilię Bożego Narodzenia (24 grudnia 1939 r.) przyniosła wspomnienie napaści sowieckiej na Finlandię (rozpoczętej 30 listopada tego roku) oraz wzmiankę o niemieckiej odmowie zgody na międzynarodową pomoc charytatywną dla Polski ${ }^{42}$. Papież nie wymieniał jednak Sowietów de nomine jako współsprawców inwazji Polski i agresji na Finlandię, stosując taktykę podobną do tej jaką praktykował w przypadku III Rzeszy jako najeźdźcy Polski.

W tym przemówieniu Najwyższy Pasterz sformułował pięć warunków sprawiedliwego pokoju, a wśród nich wprowadził postulat najważniejszy poszanowanie „niepodległości narodów wielkich i małych, potężnych i słabych". Był to program, który na pewno odnosił się do Polski.

Zadaniem istotnym, które stawiano sobie na uchodźstwie, były starania, aby zainteresować Stolicę Apostolską polską definicją celów wojny, a przede wszystkim polską oceną jej charakteru. Klarownie wyraził tę myśl szef MSZ w rządzie gen. Władysława Sikorskiego Zaleski. Pisał on 19 lutego 1940 r. do ambasadora Papéego, że „wojna obecna jest wojną totalną nie tylko co do środków, ale i co do celów; nie jest wojną jedynie pomiędzy dwoma ugrupowaniami państw o sprzecznych interesach politycznych czy gospodarczych, lecz przede wszystkim walką barbarzyństwa z ustrojem opartym na etyce chrześcijańskiej oraz na zasadach prawa rzymskiego"43.

Do watykańskiego Sekretariatu Stanu ambasada polska zwracała się wielokrotnie o pomoc w różnych sprawach. I w kwestii uwięzionych 6 listopada 1939 r. profesorów krakowskich, i w sprawie jeńców polskich w obozie Miranda El Ebro w Hiszpanii.

${ }^{41}$ Amb. Papée do min. Raczyńskiego, 3 września 1942 r., IPMS, Ambasada RP przy Watykanie, sygn. A. 44.122/28.

${ }^{42}$ Treść podają: Actes du Saint-Siège, t. 1, s. 353-361. Do tej kwestii mamy też interesujący raport brytyjskiego posła Osborna z 27 grudnia 1939 r. dla lorda Halifax w Londynie, Foreign Office, 371/24405, C.89/89/18.

${ }^{43}$ Instrukcja Zaleskiego z 19 lutego 1940 r., IPMS, Ambasada RP przy Watykanie, sygn. A. 44. 122/22. 
Dążenie rządu polskiego na uchodźstwie do uzyskania poparcia Stolicy Apostolskiej w toczącej się wojnie stanowiło jeden z priorytetów politycznych. Charakteryzując główne założenia polskiej polityki zagranicznej, w przemówieniu na sesji Rady Narodowej w Angers 4 kwietnia 1940 r. minister Zaleski wymienił Stolicę Apostolską przed Stanami Zjednoczonymi, co z pewnością jest wiele mówiące. Stwierdzał, że „na pierwszy plan wysuwa się przede wszystkim owo Mocarstwo Moralne, jakim jest Stolica Apostolska. Wiemy, do jakich wyżyn wzrósł autorytet Głowy Chrześcijaństwa podczas pontyfikatu Piusa XI. Wojna, w której sprzymierzyli się dwaj wrogowie wszelkiej wiary, musiała specjalnie uwypuklić rolę Watykanu, jako uosobienia moralności i sumienia ludzkości. Toteż godny następca swego poprzednika, Pius XII skupił na Stolicy Piotrowej nadzieje wszystkich tych, którzy ufają w tryumf sprawiedliwości. Jestem przekonany, że wyrażę uczucia wszystkich Polaków, gdy złożę na tym miejscu Jego Świątobliwości pełne szacunku podziękowania za wyrazy otuchy, pociechy i nadziei, jakie wypowiadał wielokrotnie pod adresem Polski" ${ }^{\prime 4}$.

Tak brzmiały słowa kierownika polskiej dyplomacji, ale pro foro interno, w kręgu swych najbliższych współpracowników generał Sikorski wypowiadał o polityce Stolicy Apostolskiej wiele bardzo gorzkich uwag, a niektóre z nich zapisał w swoim Dzienniku wypadków 16 listopada 1939 r. Karol Estreicher, jego sekretarz w Prezydium Rady Ministrów na uchodźstwie:

„Na polityce Watykanu ciąży przede wszystkim zwycięstwo faszyzmu. Głupota komunistów w stosunku do religii sprawiła, że kościoły wszystkich wyznań wolą faszyzm niż bolszewizm. Księża słusznie boją się, że będą wymordowani. (...) Musimy skończyć z legendą, że Watykan był nam życzliwy po I wojnie światowej. Nic podobnego. Watykan ma własną politykę sympatii z bogatymi uporządkowanymi Niemcami. Pius XI nie taił, że faszyzm i hitleryzm stanowi w Europie najsilniejszą zaporę przeciw bolszewizmowi - a nie my. My jesteśmy tylko przeszkodą w pogodzeniu katolicyzmu z prawosławiem. (...) Pacelli jest jeszcze silniej związany z Niemcami: Niemcy mu we wszystkim imponują. One w jego mniemaniu ocaliły Hiszpanię"45.

${ }_{44}$ Instrukcja Jana Ciechanowskiego (sekretarza generalnego MSZ) do placówek dyplomatycznych, 4 kwietnia 1940 r., IPMS, Ambasada RP przy Watykanie, sygn. A. 44. $122 / 22$.

45 K. Estreicher jr., Dziennik wypadków, t. 1: 1939-1945, Pałac Sztuki, Kraków 2001, s. $60-61$. 
:::: Marek Kornat, Stolica Apostolska w polskiej polityce zagranicznej...

Generał nie zgodził się z uwagą obecnego przy tej wypowiedzi Józefa Retingera, że „Coś musi papież zrobić dla Polski”. „Nic nie zrobi! - mówił Sikorski. W Watykanie nas nie lubią - ani Skrzyński, ani Papée nie są w stanie wskórać czegokolwiek. Coś tam papież bąknie na wilię, a biskupy to rozprowadzą, ale żadnej klątwy na Hitlera nie rzuci, nie potępi, nie zorganizuje żadnej akcji, bo Hitler mu się podoba (...) Większa jest obawa w Watykanie przed bolszewizmem niż przed hitleryzmem"46. Słowa te polski premier wypowiadał spontanicznie w uczuciu gniewu, że akcja dyplomacji polskiej, aby Pius XII potępił Niemcy, spełzła na niczym. Nie miał generał racji, że Hitler papieżowi „się podoba”, ale w swojej ocenie polityki Stolicy Apostolskiej poddawał się nastrojom ówczesnej opinii polskiej.

Jest niewątpliwe, że w Watykanie dysponowano miarodajnymi informacjami o zbrodniach niemieckich, a nawet doradzano - ,jak najszersze wyzyskanie propagandystyczne okrucieństw, prześladowań i nadużyć niemieckich w Polsce i dopytuje się o naszą czarną księgę. W związku z tym wydaje się stąd pożądane ogłoszenie czarnej księgi już w najbliższym czasie $^{\prime 47}$. Uzyskanie jednoznacznej deklaracji papieskiej było jednak poza zasięgiem możliwości.

29 grudnia 1939 r. Papée został przyjęty na audiencji przez Piusa XII i była to pierwsza od 2 września audiencja prywatna polskiego ambasadora. Papież mówił o niebezpieczeństwie bolszewickim”, „podkreślając jego powagę i konieczność przeciwdziałania"48. W swoim Diariuszu ambasador zapisał: „Bardzo dobra audiencja”. Udzielając zaś błogosławieństwa papież dodał: „pour la résurrection et la grandeur de la Pologne" ${ }^{\text {"49 }}$.

W rozmowach dyplomatycznych Pius XII wypowiadał się w sprawie polskiej z oznakami niewątpliwej sympatii. Amerykański zastępca sekretarza stanu Sumner Welles po rozmowie z papieżem w lutym 1940 r. mówił gen. Sikorskiemu miesiąc później, że papież „jest Wam bardzo życzliwy” i nie mamy powodu wątpić, że amerykański polityk takie właśnie wraże-

46 Ibidem, s. 61.

47 Papée do MSZ, 9 kwietnia 1940 r., IPMS, Ambasada RP przy Watykanie, sygn. A. 44.122/22.

${ }_{48}$ Raport amb. Papée z 31 grudnia 1939 r., zob. M. Kornat, op.cit., s. 136-137.

49 „Diariusz" amb. Papéego, notatka z 29 grudnia 1939 r., Papieski Instytut Studiów Kościelnych, Archiwum Ambasadora K. Papéego, karton 1. 
nie odniósł w Rzymie amerykański polityk ${ }^{50}$. Publicznie jednak Pius XII nie wychodził poza ramy neutralności. W Watykanie, zwłaszcza w cztery oczy, okazują nam wprawdzie maksimum sympatii, ale z chwilą kiedy trzeba by tę sympatię na zewnątrz zamanifestować zaraz biorą wodę w usta" - zanotował Jan Szembek, po rozmowie z ambasadorami Papéem i Wieniawą-Długoszowskim w Wenecji 22 września $1939 \mathrm{r}^{51}$ Ten stan rzeczy, mimo nieustających wysiłków emigracyjnej dyplomacji polskiej i biskupów polskich (na czele z przebywającym na wygnaniu prymasem Hlondem i kierującym pracami episkopatu w kraju ks. Adamem Sapiehą) - nie uległ już do końca wojny zmianie.

Papée, w raporcie z 6 października 1939 r., określił stanowisko Watykanu jako „arcyostrożne i nieujawniające się na zewnątrz” ${ }^{2}$. Dawał też wyraz wierze w to, że Pius XII „przechodzi wyraźną i korzystną dla nas ewolucję"53. „Watykan jest niezmiennie po naszej stronie - pisał do Zaleskiego ambasador w innym ze swych raportów. „Zewnętrzne wystąpienia Stolicy Apostolskiej nie idą jednak po linii tych sympatii, gdyż są hamowane przez zwykłą Watykanowi ostrożność, zwykłą Włochom najwyższą oględność; przez wzgląd na ostatecznie niewykluczone, choć nieprawdopodobne zwycięstwo Niemców, przez obawę pogorszenia represji wskutek rozdrażnienia hitlerowców, przez uległość wpływom włoskim, które w dziedzinie dyplomacji służą Berlinowi - i inne podobne, w istocie uboczne motywy"54.

11 marca 1940 r. Pius XII przyjął ministra spraw zagranicznych Rzeszy Joachima von Ribbentropa ${ }^{55}$. Wizyta Ribbentropa - Watykanowi „bardzo nie na rękę” i Ojciec Św. „niechętnie się na nią zgodził. Papież spotkał się

${ }^{50}$ M. Zgórniak (red.), W. Rojek (oprac.), Protokoły posiedzeń Rady Ministrów Rzeczypospolitej Polskiej, t. 1, „Secesja” Kraków, 1994, s. 243 (załącznik do protokołu z 16 marca $1940 \mathrm{r}$.).

51 J. Szembek, Diariusz, wrzesień - grudzień 1939, wyd. B. Grzeloński, PAX, Warszawa 1989, s. 70-71.

${ }^{52}$ Papée do MSZ, 6 października 1939 r., IPMS, Ambasada RP przy Watykanie, sygn. A. 44.122/20.

53 Raport amb. Papéego, 26 stycznia 1940 r., IPMS, Ambasada RP przy Watykanie, sygn. A. 44.122/21.

${ }_{54}$ Papée do min. Zaleskiego, 31 stycznia 1940 r., IPMS, Ambasada RP przy Watykanie, sygn. A. 44.122/21.

${ }_{55}$ Niemiecka notatka z tej audiencji: Documents on German Foreign Policy, series D: (1937-1945), vol. 8, Washington 1954, dok. 668, s. 896-898. 
z długim monologiem Ribbentropa, a próby „uzyskania dostępu” do Polski poprzez zgodę na wysłanie wizytatora papieskiego - nie dały ostatecznie rezultatu ${ }^{56}$. Niemieckiego ministra spraw zagranicznych przyjął też kardynał sekretarz stanu Maglione, który zwrócił się o umożliwienie akcji charytatywnej dla Polski, co było jedyną wzmianką o jej sprawie ${ }^{57}$.

Trzeba powiedzieć jasno. Papież nie mógł audiencji tej odmówić, skoro był o nią proszony, a poza tym skoro pragnął utrzymać linię ścisłej neutralności w toczącej się wojnie. Propaganda niemiecka wykorzystała jednak tę wizytę jako dowód aprobaty papieskiej dla polityki III Rzeszy. W ocenie ambasadora RP przy Watykanie „marcowa audiencja Ribbentropa u Papieża była nieszczęściem. Zgadza się z tezą, że Niemcy z całym cynizmem wyzyskali ją, by rzucić piaskiem w oczy katolikom całego świata, a zwłaszcza krajów okupowanych. W Polsce twierdzili wprost i twierdzą nadal, że Papież aprobuje politykę Rzeszy i akceptuje zmiany terytorialne dokonane siłą przez Hitlera w Europie”58. 27 lutego 1940 r. Papée pisał, że papież „nie zrezygnował jeszcze z wystąpienia z pokojową w odpowiednim momencie". W tym celu przyjął Wellesa i Myrona Taylora - przedstawicieli rządu amerykańskiego ${ }^{59}$. Welles odbył, jak wiadomo, z polecenia Roosevelta podróż po Europie w styczniu - marcu 1940 r. i miał za zadanie uzyskać rozeznanie czy jest możliwy kompromisowy pokój.

Doraźnie, za najważniejszy nakaz watykańskiej racji stanu Pius XII uważał umocnienie włoskiej non-beligerenza, tak długo jak to możliwe. Papież bez wątpienia pragnął odegrać trudną bliżej do zrekonstruowania rolę mediatora w stosunkach włosko-francuskich. Ambasador André François-Poncet 26 maja 1940 r. powiedział papieżowi, że „Francja jest gotowa do dużych ustępstw"60. Przystąpienie Włoch do wojny 10 czerwca 1940 r. było nie tylko wielką porażką dyplomacji watykańskiej, ale i osobistą porażką

56 Raport amb. Papéego, 18 marca 1940 r., IPMS, Ambasada RP przy Watykanie, sygn. A. 44.115/2.

57 Notatka watykańska z rozmowy kard. Maglione z v. Ribbentropem - zob. Actes du Saint-Siège, t. 1, s. 393.

${ }_{58}$ Notatka amb. Papéego z rozmowy z msgr Montinim, 20 września 1940 r., IPMS, Ambasada RP przy Watykanie, sygn. A. 44.122/22.

59 Raport amb. Papéego, 1 marca 1940 r., IPMS, Ambasada RP przy Watykanie, sygn. A. 44.122/21

60 Pisze o tym: R. De Felice, Mussolini il duce. Lo Stato totalitario, t. 2: 1936-1940, Einaudi, Torino 1981, s. 831. 
Piusa XII, chociaż oczywiście nie był on w stanie zatrzymać Mussoliniego na drodze do wojny ${ }^{61}$. Decyzja włoskiego dyktatora, aby wystąpić zbrojnie przeciwko Francji dowodziła przede wszystkim, że dopatrywanie się przez polityków zachodnich znacznego politycznego wpływu Watykanu na Włochy było nieuzasadnione ${ }^{62}$. Podkreślić należy, że przystąpienie Włoch do wojny wzmogło te tendencje w polityce Stolicy Apostolskiej, które prowadziły do podtrzymywania zasady neutralności za wszelką cenę.

W związku z przystąpieniem Włoch do wojny 10 czerwca 1940 r. i nieuznaniem przez Włochy eksterytorialności placówek obcych przy Stolicy Apostolskiej Pius XII zaprosił Papéego, aby, wraz z ograniczonym personelem ambasady, zamieszkał w Hospicjum św. Marty (na terenie Watykanu) i kontynuował misję $e^{63}$. MSZ polskiego rządu na uchodźstwie wydało komunikat, że „Ambasada RP przy Stolicy Apostolskiej została zmuszona przez rząd włoski do przeniesienia się do Watykanu na równi z innymi ambasadami tych państw, z którymi Włochy znajdują się w stanie wojny"64. Polski rząd nie ogłosił - mimo wyraźnych nacisków brytyjskiego sojusznika - że Polska znajduje się w stanie wojny z Włochami ${ }^{65}$. Ambasador Wieniawa-Długoszowski przekazał opiekę nad interesami polskimi we Włoszech Stolicy Apostolskiej i obowiązki te objął nuncjusz przy Kwirynale monsignor Francesco Borgongini-Duca ${ }^{66}$.

${ }^{61}$ Przed 10 czerwca papież osobiście zwracał się do Mussoliniego aż trzykrotnie apelując o nieprzystępowanie do wojny (do tej sprawy raport amb. Papéego z 10 czerwca 1940 r., IPMS, Ambasada RP przy Watykanie, sygn. A. 44. 115/2).

${ }^{62}$ Count C. Sforza, Contemporary Italy. Its Intellectual and Moral Origins, F. Muller, London 1946, s. 285.

63 Do tych spraw wspomnienia ambasadora: Kartki z pamiętnika, „Wiadomości”, nr 723 oraz Życie w Santa Marta - 7.02.1960, ibidem, 29.05.1960, nr 739. W Hospicjum św. Marty znalazły schronienie również inne placówki alianckie: ambasada francuska, poselstwo brytyjskie, poselstwo amerykańskie, później zaś i misja jugosłowiańska.

${ }^{64}$ Instrukcja MSZ do placówek, 22 sierpnia 1940 r., IPMS, Ambasada RP przy Watykanie, sygn. A. 44. 122/23.

${ }_{65}$ Tło sprawy daje Krzysztof Strzałka w monografii, Między przyjaźniq a wrogością. Z dziejów stosunków polsko-włoskich (1939-1945), Arcana, Kraków 2001, s. 177-187. Pomysł, aby personel ambasady przy Kwirynale dołączyć do składu ambasady przy Watykanie, nie został zrealizowany - ibidem, s. 183.

${ }^{66}$ Amb. Papée do min. Zaleskiego, 10 czerwca 1940 r., IPMS, Ambasada RP przy Watykanie, sygn. A. 44.122/22. Sekretariat Stanu aprobował to rozwiązanie notą do ambasady RP z tego samego dnia. 
:::: Marek Kornat, Stolica Apostolska w polskiej polityce zagranicznej...

Rezydowanie w Hospicjum św. Marty będzie wiązało się wieloma poważanym uciążliwościami. Sytuacja ta stworzyła poważne trudności w funkcjonowaniu łączności z rządem RP na uchodźstwie. 15 listopada 1940 r. ks. Meysztowicz skarżył się Montiniemu, że:

„maniery tajnej policji watykańskiej wobec rezydujących w Watykanie dyplomatów są nieodpowiednie, że razi nas to, iż na każdym kroku wyrasta przed nami jegomość w żółtym palcie i nasuniętym na oczy kapeluszu, przyglądający się nam bacznie i coś zapisujący w notesie; że nawet w sieniach naszego domu taki sterczy i że ja sam widzę takiego nawet, gdy Mszę odprawiam w kościele, z nieodstępnym notesem, niefatygującego się nawet ukryć za kolumną czy konfesjonałem" ${ }^{\prime \prime}$.

Stanowcze żądania władz włoskich - zawarte np. w nocie ambasady włoskiej przy Watykanie do Sekretariatu Stanu z 13 lipca 1940 r. - zmierzały do wyegzekwowania maksymalnego ograniczenia roli misji państw alianckich przy Watykanie. W porozumienie przedstawicielstwa wielokrotnie kierowały przeciwko temu stanowcze protesty - ostatni w postaci aide-memoire z 18 marca $1943 \mathrm{r}^{68}$

W takich warunkach funkcjonowała ambasada RP do wyzwolenia Rzymu 5 czerwca 1944 r., przetrwała również najtrudniejszy okres niemieckiej okupacji Rzymu od 8 września 1943 do czerwca 1944 r. Trudno nie podkreślić, że była to bardzo ciężka misja. Niejednokrotnie pojawiał się nastrój rezygnacji i zwątpienia, czego świadectwo znajdujemy w niepublikowanym Diariuszu ambasadora. „Męczę się dzisiaj - zapisał ambasador 27 grudnia 1940 r. „Boże mój, czy to wszystko na coś się przyda?”69. Dochodzące z kraju informacje wzmacniały nastrój niepewności i pesymizmu i tak 30 stycznia 1941 r. pod wrażeniem docierających z okupowanego kraju wiadomości o zbrodniach zanotował: „Straszne wiadomości z Polski. Niemcy likwidują (wywożą do obozów) całą inteligencję. Eksterminacja"70.

\footnotetext{
${ }^{67}$ Notatka amb. Papéego z 15 listopada 1940 r., IPMS, Ambasada RP przy Watykanie, sygn. A. 44.122/22.

${ }^{68}$ IPMS, Ambasada RP przy Watykanie, sygn. A. 44. 115/6.

69 „Diariusz” amb. Papéego, notatka z 27 grudnia 1940 r.

${ }^{70}$ Ibidem.
} 
Ewakuacja rządu RP na uchodźstwie do Londynu w czerwcu 1940 r. pociągnęła za sobą nową anomalię w stosunkach dyplomatycznych ze Stolicą Apostolską. Prałat Alfredo Pacini otrzymał od Sekretariatu Stanu polecenie udania się do Londynu, ale jego wyjazd do Londynu okazał się niemożliwy, z powodu nieudzielenia mu wizy przez rząd brytyjski ${ }^{71}$.

Zwycięstwo niemieckie nad Francją w czerwcu 1940 r. wywarło w Watykanie silne wrażenie. Wrażenie to było zresztą silne w całej ówczesnej Europie. Na poczynania papieża miało ono bardzo wymierny wpływ. Przypomnieć należy, że jeszcze przed uderzeniem na Francję Pius XII pozostawał pod wrażeniem wydatnej przewagi niemieckiej oraz słabości i bierności mocarstw zachodnich. Cytując opinię „,jednego z dobrze poinformowanych Kardynałów Kurialnych" Papée pisał 22 kwietnia do ministra spraw zagranicznych w Angers, iż „Pius XII przeświadczony jest o tym, że zwycięstwo niemieckie jest nieuniknione i boi się tego bardzo". Ambasador od siebie dopowiadał, że "taki był od początku wojny pogląd Piusa XII i nie wiele się w ciągu wojny pod tym względem zmieniło"72.

Kilkakrotnie ambasada zwracała uwagę Watykanu na to, że nieprzyjaciel wykorzystuje bierność Stolicy Apostolskiej, która jest niezrozumiała w okupowanym kraju. Konieczność uświadamiania Stolicy Apostolskiej o niezadowoleniu z milczenia papieża w obliczu zbrodni ${ }^{73}$. Papież ogromnie czuły na wszelką krytykę i naciski na niego nieskuteczne, konieczność dozowania informacji dla niego niekorzystnych - bo reakcja jest z reguły odwrotna do zamierzonego celu.

Rozmawiając z watykańskimi urzędnikami zwracano im uwagę, że okupant „cynicznie i przewrotnie” interpretuje stanowisko papieża „przy każdej sposobności"74. Jako wielce dwuznaczną uważano misję nuncjusza Cesare Orsenigo w Berlinie. W sierpniu 1940 r. zwrócił na to uwagę Stolicy Apostolskiej abp Sapieha, działając poprzez o. Włodzimierza Ledóchow-

71 Z. Waszkiewicz, op.cit., s. 52.

72 Amb. Papée do min. Zaleskiego, 22 kwietnia 1941 r., IPMS, Ambasada RP przy Watykanie, sygn. A. 44.115/4.

73 Amb. Papée do min. Raczyńskiego, 11 listopada 1941 r., IPMS, Ambasada RP przy Watykanie, sygn. A. 44.122/26.

74 Raport amb. Papéego, 20 września 1940 r., IPMS, Ambasada RP przy Watykanie, sygn. A. 44.122/23. 
:::: Marek Kornat, Stolica Apostolska w polskiej polityce zagranicznej...

skiego, generała Jezuitów ${ }^{75}$. 9 września 1942 r. Papée złoży w tej sprawie ostry protest. Również Karolina Lanckrońska wspominała z okresu swej służby okupacyjnej w AK, że arcybiskup Sapieha miał jedno tylko życzenie: aby Orsenigo nie wygłaszał przemówień kolportowanych szeroko przez propagandę hitlerowską i oddziaływujących bardzo ujemnie zwłaszcza na polskich księży więzionych w Sachsenhausen ${ }^{76}$.

Polskie kierownictwo polityczne pragnęło zużytkować i wykorzystać to, co udało się od papieża uzyskać. Zapewne, w wypowiedziach i aktach urzędowych papieża znajdziemy pokrycie dla tych słów, ale w dobie straszliwej wojny społeczność międzynarodowa oczekiwała czegoś więcej, pragnęła przede wszystkim rezygnacji z języka dyplomacji, który był naturalnym językiem Piusa XII, językiem pełnym aluzji i sformułowań ogólnych, dających się rozmaicie interpretować.

Co udało się osiągnąć dyplomacji polskiej w działaniach wobec Watykanu?

Przede wszystkim Stolica Apostolska uznała ciągłość prawnopaństwowo Rzeczypospolitej mimo okupacji i rozbioru terytorium państwa. Kontynuowała stosunki dyplomatyczne z rządem, który utracił terytorium, ale zachował podmiotowość $\mathrm{w}$ rozumieniu prawa międzynarodowego. 0 uznaniu przez Watykan rządu RP na uchodźstwie przesądziło definitywnie - jak się wydaje - uznanie go ze strony państw neutralnych i zasadnicze stanowisko społeczności międzynarodowej, nieuznającej podboju terytorium Polski.

Optyka polska zderzała się z optyką Stolicy Apostolskiej. Polska teza o wyjątkowości wojny rozpoczętej przez Niemcy w sposób bezprecedensowo zbrodniczy, która pozostaje inna niż poprzednie - spotykała się z kontrargumentacją watykańską o potrzebie neutralności papiestwa jako ponadnarodowej instancji mimo wszelkich przeciwności.

75 Przypomniał to posunięcie ks. Z. Zieliński, op.cit., s. 731.

${ }^{76}$ K. Lanckorońska, Wspomnienia wojenne 22 IX 1939 - 5 IV 1945, wstęp L. Kalinowski, E. Orman, Społeczny Instytut Wydawniczy Znak, Kraków 2002, s. 63-64. O „niechęci kleru” polskiego do nuncjusza w Berlinie wspomina też Luciana Frassati-Gawrońska w pamiętniku: Przeznaczenie nie omija Warszawy, tłum. J. Tygielski, Wydawnictwo Więź, Warszawa 2003, s. 228. 
Polityka Stolicy Apostolskiej wobec sprawy Polski była funkcją podstawowych założeń programowych kształtowanych w realiach wojny europejskiej. Należało do nich między innymi przekonanie Piusa XII i jego otoczenia, że Watykan powinien zachować neutralność chociażby po to, aby w chwili sposobnej wystąpić z własną inicjatywą mediacyjną.

W działaniach wobec Stolicy Apostolskiej dyplomacja polska nie była w stanie osiągnąć więcej niż uzyskała. Argument, iż upadek Polski stanowi wydatne osłabienie siły katolicyzmu światowego niewątpliwie docierał do Piusa XII, ale spotykał się z innym argumentem - o trudnym do przecenienia znaczeniu niemieckiego katolicyzmu, którego Kurii Rzymskiej nie wolno odtrącić.

W relacjach Polska - Watykan zderzały się wreszcie dwa porządki działania. Dyplomacja każdego państwa ma na celu osiągać realizację jego racji stanu. Swoją rację stanu ma także i Kościół. Miał ją i Pius XII. Ale z powodu konieczności stawania ponad sporami poszczególnych narodów „Papież musi postępować oględnie i powoli” - jak to ujął kardynał Hlond ${ }^{77}$.

Utworzony w Paryżu 1 października, a od 20 listopada 1939 r. rezydujący w Angers rząd polski na uchodźstwie postrzegał Stolicę Apostolską jako doniosły czynnik polityki światowej. Stolica Apostolska pozostawała dla niego najważniejszym państwem neutralnym obok Stanów Zjednoczonych - w okresie między wrześniem 1939 a czerwcem 1940 r. mających również taki status międzynarodowoprawny.

Sprawy Polski nie były jednak dla Stolicy Apostolskiej po wrześniu 1939 r. „pierwszoplanowymi”, chociażby dlatego, że perspektywa wyzwolenia Rzeczypospolitej oddalała się i komplikowała - jak słusznie ujęła to trzydzieści pięć lat temu Zofia Waszkiewiczowa ${ }^{78}$. W czerwcu 1940 r. w związku z przystąpieniem Italii do wojny, wolność Stolicy Apostolskiej nie została zniweczona, ale poważnie ograniczona. Z chwilą upadku Francji zwycięstwo sprzymierzonych stawało się ewentualnością odległą w czasie, jeśli w ogóle możliwe ${ }^{79}$. Pius XII umocnił swój kurs na rzecz polityki „neu-

\footnotetext{
77 ks. W. Necel TChr. (oprac.), Z notatnika Kardynała Augusta Hlonda, Hlondianum, Poznań 1995, s. 365.

78 Z. Waszkiewicz, op.cit., s. 62.

79 Autor niniejszych słów zbiera materiał źródłowy do studium o watykańskich opiniach na temat, kto wygra II wojnę światową, z okresu 1940-1942.
} 
:::: Marek Kornat, Stolica Apostolska w polskiej polityce zagranicznej...

tralności absolutnej" ${ }^{\prime 0}$. Ale to już są problemy, którym poświęcić by należało osobne źródłowe studium, najlepiej w oparciu o pierwszorzędne akta watykańskiego Sekretariatu Stanu.

Marek Kornat

\section{The Holy See In Polish Foreign Policy OF THE GOVERNMENT ON EXILE (SePtember 1939 - June 1940)}

The article is devoted to the reexamining of the policy of Polish Government on exile toward the Holy See after Poland's defeat in September 1939 and the reestablishment of the legal authorities of Poland in France, under President Raczkiewicz and General Sikorski as Prime Minister. Terminus ad quem of the narration is the collapse of France and transfer of the Government of Poland to London in June 1940. Problems of Vatican's perception of Polish Question is discussed on the basis of Polish archival documents, especially those of Polish Embassy to the Holy See. Vatican-Polish relations at the beginning of the World War II require special attention because the last treatment of this highly debatable problem was made in historiography by Zofia Waszkiewicz more than thirty five years ago in her monograph Polityka Watykanu wobec Polski 1939-1945 [Policy of the Vatican toward Poland 1939-1945] (Warsaw 1980). How much Polish diplomacy achieved fighting for the Holy See's support against Nazi Germany? Two things must be said. Firstly, the Holy See recognized the legal continuity of Polish State after the German-Soviet occupation of Poland's territory in September 1939, but did not sent the papal nuncio to Angers, when Polish Government resided. Secondly, Polish thesis on the special significance of Polish Question as the test-case of international justice received the positive response of the Pope Pius XII in his encyclical Summi Pontificatus published on October 20 1939, but the guidelines of Vatican's policy were based on the doctrine of strict neutrality of the Papacy in the international relations. It did not permit for Papal condemnation ex officio of the Nazi crimes and criminal policy of extermination in Poland.

80 Tę politykę Watykanu analizowałem w artykule: Papież Pius XII i jego koncepcja „neutralności absolutnej” Stolicy Apostolskiej w stosunkach międzynarodowych (1939-1945). Przypadek Polski, „Zagłada Żydów: Studia i Materiały: Pismo Centrum Badań nad Zagładą Żydów Instytutu Filozofii i Socjologii Polskiej Akademii Nauk” 2009, nr 5, s. $104-127$. 